\title{
УДК: 631.67:631.43+528
}

\section{IRRIGATION DEVELOPMENT OF ARYS-TURKESTAN MASSIV IN SOUTH KAZAKHSTAN \\ ИРРИГАЦИОННОЕ ОСВОЕНИЕ АРЫСЬ-ТУРКЕСТАНСКОГО МАССИВА В ЮЖНОМ КАЗАХСТАНЕ}

Starodubtsev V.M. / Стародубцев B.M.

National University of Life and Environmental Sciences of Ukraine Kyiv, Heroiv Oborony st., 15, 03041 Национальный университет биоресурсов и природопользования Украины Киев, ул. Героев Обороны, 15, 03041

Beksultanov М.К. / Бексултанов М.К. Kalibekova А. / Калыбекова А. Nurimbetov R.I. / Нуримбетов Р.И. Kazakh National Agrarian University, AgriTech-Hub, Kazakhstan, 050010, Almaty, ul. Abay, 8 Казахский национальный аграрный университет, Агротех-Хаб, Алматы, ул. Абая 8

Аннотация:Рассмотрена история проектирования и освоения Арысь-Туркестанской оросительной системы, созданной на предгорной равнине в Южном Казахстане. Отмечены специфические мелиоративные особенности этой территории, представляющей собой периферическую часть слившихся конусов выноса юго-западных склонов хребта Каратау. Особое внимание уделено влиянию ирригационного Бугунского водохранилища на смежные территории, в особенности на процессы засоления, подтопления и эрозии почв. На Арысском (АТМ) и Туркестанском (ТМК) каналах выявлень с помощью дронов $и$ картографического сервиса Google Earth участки непроизводительных потерь воды из-за состояния гидротехнических сооружений. Проанализирована динамика развития орочения с учетом засоления и подтопления почв, применения дренажа. Предложены мероприятия по улучшению водообеспеченности оросительной системы.

Ключевые слова: конусы выноса, орочение, засоление почв, подтопление, дренаж.

1. Введение. Ирригационное освоение предгорной равнины в Южном Казахстане имело огромное значение для социально-экономического развития этого региона. Его техническая реализация была сложной, длительной, противоречивой и все же успешной. Выращиваемые здесь технические, зерновые, плодо-овощные и кормовые культуры являются стратегическим ресурсом ныне Туркестанской области. А население получило рабочие места, приобрело бесценный опыт орошения и мелиорации, на массиве увеличивается население, строятся новые поселки. Даже вид из космоса на АрысьТуркестанскую систему (рис. 1) вызывает чувство оптимизма и понимание важности и своевременности обеспечения пресной водой этого огромного региона. Тем не менее, к сегодняшним дням накопились проблемы, требующие неотложного решения. Это прежде всего нарастающий недостаток воды для орошения. Он обусловлен: 1) заиливанием Бугунского водохранилища, 2) фильтрационными потерями из магистральных каналов, проложенных при неглубоком залегании галечниковых отложений без достаточных противофильтрационных мер (Туркестанский канал), и в лессовых отложениях, имеющих заметные фильтрационные и просадочные свойства (Арысский канал), 3) потерями в распределительных каналах первого порядка, 4) несанкционированными отборами воды для орошения дополнительных 
площадей, 5) локальными потерями воды на отдельных участках каналов (магистральных и распределительных) при не всегда хорошем состоянии гидротехнических сооружений, приводящими к затоплению и подтоплению прилегающих к ним земель, 6) использованием повышенных поливных и оросительных норм и других причин.

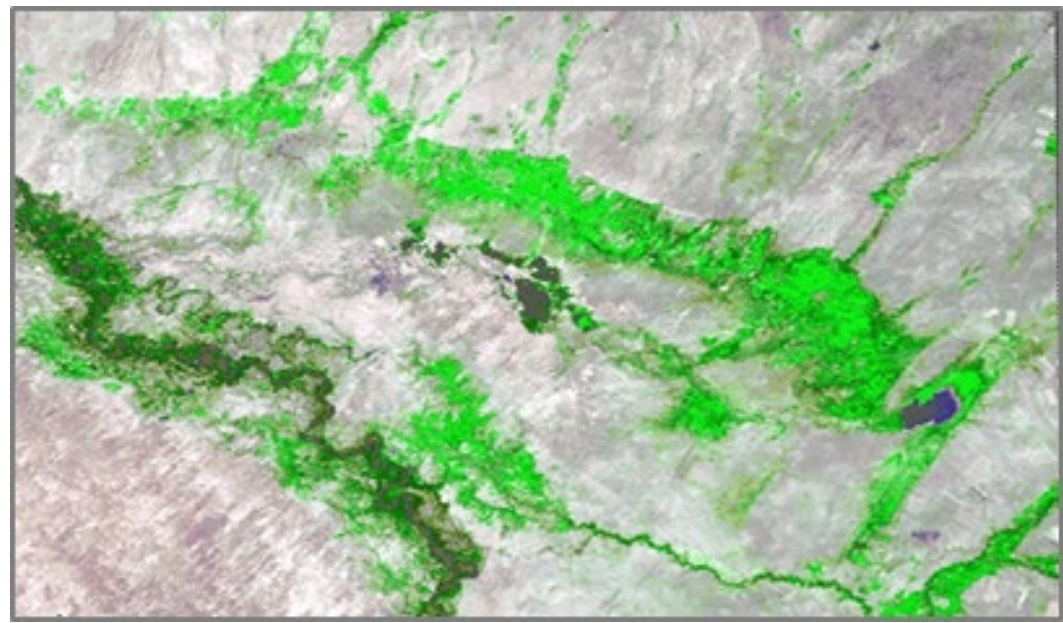

\section{Рис.1. Арысь-Туркестанская оросительная система - вид со спутника Ландсат-8, 2019 г.}

Для выявления участков с потерями воды из оросительных сетей, несанкционированного отбора воды различными водопользователями, сформулировано задание (проект) применить информационные методы и дистанционное зондирование территории, чтобы оперативно устранять такие непроизводительные потери, а также проанализировать происходящие на оросительной системе процессы. Проект выполняет «Корпоративный фонд «Агротехнологический хаб» при Казахском национальном аграрном университете, исполнители - Бексултанов М.К., Калыбекова А., Нуримбетов Р., консультант - профессор Стародубцев В.М. из Национального университета биоресурсов и природопользования Украины, который проводил почвенномелиоративные исследования на этой системе еще в 60-70-е годы [7].

Идея строительства Арысь-Туркестанской оросительной системы была оформлена в схематическом проекте еще в 1948 г., а проектное задание составлено в 1953 г. институтом «Казгипроводэлектро» (длина канала 194,5 км, емкость Бугунского водохранилища 370 млн. куб. м, площадь правильного орошения 70,5 тыс. га, лиманного орошения 53,8 тыс. га, площадь хлопчатника 28,4 тыс. га). Ирригационная сеть запроектирована в земляных руслах, меры борьбы с фильтрацией не предусмотрены, дренаж и сбросная сеть не запроектированы.

Почвенно-мелиоративное обоснование к проектному заданию, выполненное в 1949-1950 гг. и уточненное изысканиями в 1952-1953 гг. («Средазгипроводхлопок) и в 1956-1958 гг. (СоюзНИИХИ), базировалось на переоценке дренирующей роли галечниковых отложений и на анализе существовавшей в то время структуры почвенного покрова, без учета изменчивости почвенно-мелиоративных и гидрогеологических условий при 
орошении. Все это и привело к строительству оросительной системы без применения инженерных мелиораций. Первые же годы освоения массива выявили недостатки такого технического решения и заставили «уточнить» проектное задание. Уточненным заданием предусмотрено освоение 121,8 тыс. га, из которых 52,4 тыс. га регулярного орошения, 53,0 тыс. га лиманного орошения и земель совхоза Дармина (цитварная полынь) - 16,4 тыс. га. Лиманное орошение в последующем было исключено из проекта. Для борьбы с подъемом грунтовых вод и засолением почв предусмотрено строительство коллекторно-дренажной сети на площади 22 тыс. га и промывки наиболее засоленных почв. Однако, по мнению рецензента С.Ф. Аверьянова [1], «намеченная в проекте площадь дренажа (22 тыс. га) является минимальной, основанной на существующем положении дела, без учета прогноза водносолевого режима почв. Эта площадь может быть условно принята как объем работ первой очереди. В недалеком будущем (1-3 года) эта площадь возрастет».

К сожалению, этот прогноз оправдался в процессе ирригационного освоения Арысь-Туркестанского массива (как и других подобных систем [5] ) в начале 1960-х годов. Наличие трудно мелиорируемых засоленных (иногда и солонцеватых) почв на массиве [4, 6], фильтрационные потери воды из Туркестанского канала, проходящего по территории с неглубоким залеганием гравийно-галечниковых отложений и не имеющего противофильтрационного покрытия, не всегда оперативное строительство дренажа (закрытого и открытого), часто неоправданное пространственное размещение дренажных систем без учета мелиоративных условий массива, а в целом и недостаточного опыта и знания особенностей мелиоративных процессов в конусах выноса предгорной равнины Каратау привели к существенному увеличению площадей засоленных почв. Солевая съемка массива, выполненная по заданию института «Союзгипрорис» рядом организаций, включая Джамбулский институт водного хозяйства (Вышпольский Ф.Ф.[2] и другие) и Институт почвоведения АН КазССР (Егоричев Г.А.[3], Стародубцев В.М. [7] и др.) показала, что площадь засоленных почв к этому времени увеличилась на 17 тыс. га.

В последующие годы освоение массива продолжалось, иногда методом проб и ошибок, особенно в области борьбы з засолением и подтоплением, строительства и эксплуатации открытого, закрытого и вертикального дренажа. Изменялись способы орошения, поливные и оросительные нормы, набор выращиваемых культур. Сложности освоения массива обусловили у некоторых водохозяйственных руководителей критическое отношение к проекту АрысьТуркестанской оросительной системы. Сложный в инженерном отношении проект, недостаток опыта освоения больших территорий с трудно мелиорируемыми засоленными почвами, недостаточное научное обоснование, а иногда и просто технические нарушения создали немало проблем на массиве. Однако они постепенно решаются.

2. Бугунское водохранилище. Для обеспечения водой АрысьТуркестанской системы в долине реки Бугунь создано водохранилище строительством Бугунской и Каражантакской плотин (рис.2). 


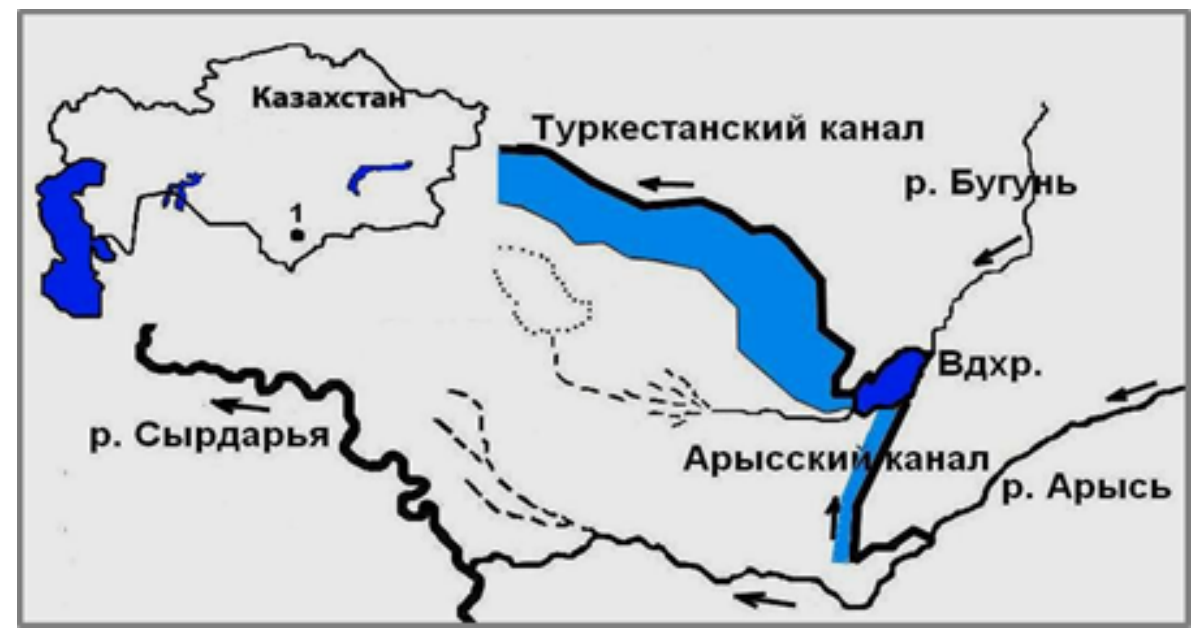

\section{Рис.2. Схема Арысь-Туркестанской оросительной системы}

Правый берег водохранилища - увалистая предгорная равнина, левый водораздел между рекой Бугунь и саем Каражантак. Площадь зеркала водохранилища 6300 га, объем - 370 млн. м³ , глубина 15-17 м. Оно накапливает сток р. Бугунь и частично - p. Арысь, наполняется ежегодно с октября по апрель, в апреле-мае поддерживается максимальный уровень, а с июня по сентябрь происходит сработка воды [8-10] на орошение до «мертвого запаса» (рис. 3).

Литология территории представлена толщей суглинков, подстилаемых на большой глубине (более 20 м) гравийно-галечниковыми отложениями. Грунтовые воды в 1951 г. (до сооружения водохранилища) в чаше проектируемого водоема залегали на глубинах: в пойме р. Бугунь - 2-5 м, а с удалением от нее погружались до 20 м. В сае Каражантак грунтовые воды вскрывались на глубине 5-10 м. Зональные почвы здесь - сероземы светлые южные [3, 4, 6], засоленные с глубины 1,0-1,5 м и до 20-30 м. Лишь в пойме Бугуни и сае Каражантак были распространены гидроморфные солончаковые почвы. В чаше созданного водохранилища почва подверглась опреснению, а на подтопленном побережье - вторичному засолению [3, 8]. Во всей чаше проектируемого водохранилища содержание солей составляло в слое 0-10 м около1200 т/га, а на всей площади чаши содержалось около 10 млн. тонн солей. В результате наполнения водохранилища, начавшегося в 1960 г., произошло подтопление почв берегов и вторичное засоление. А фильтрационными водами из чаши водоема было вымыто около 8 млн. т солей [8].

Важнейшими экологическими последствиями наполнения водохранилища являются [10]: 1) фильтрация воды и подтопление побережья (преимущественно левого берега); 2) заболачивание почв в нижнем бьефе Бугунской и Каражантакской плотин и в верховье водохранилища (в месте впадения р. Бугунь и Арысского магистрального канала (АМК); 3) засоление почв при подтоплении побережья, нижних бьефов плотин и долины сая Каражантак;4) эрозия берегов с угрозой прорыва водных масс через левый берег в сай Каражантак; 5) заиление чаши водохранилища; 6) неэффективная конструкция распределительного канала А-9, не обеспечивающая орошение запроектированных площадей; 7) зарастание крупнотравной растительностью 
побережья из-за повышенной влажности воздуха над берегами водоема (рис.4, $5)$.

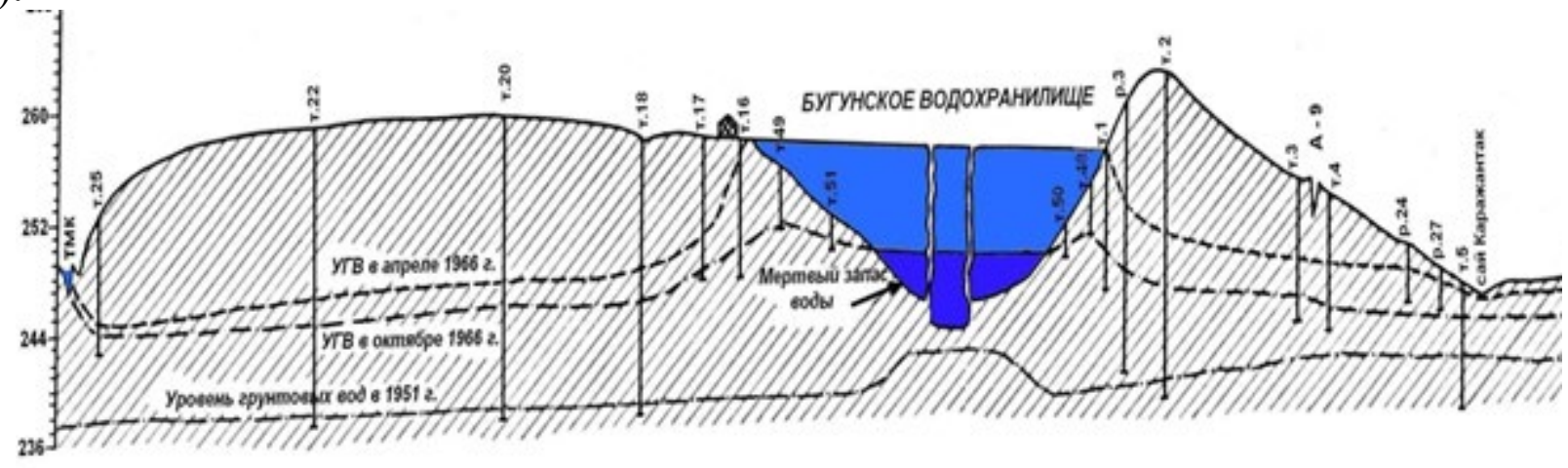

Рис.3. Поперечный профиль Бугунского водохранилища

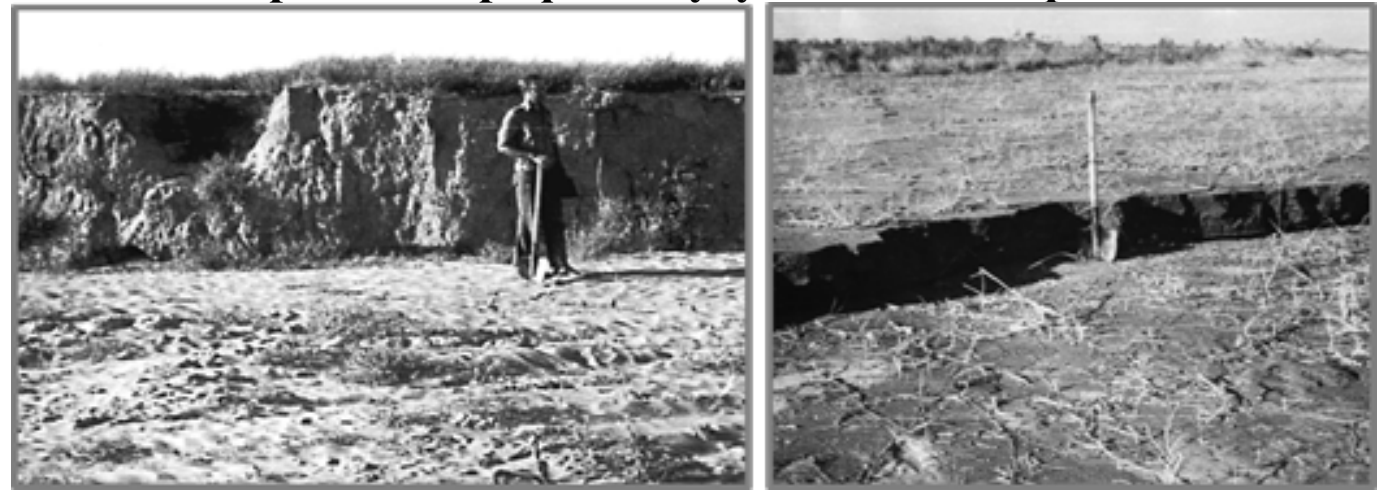

Рис.4. Эродированный берег (слева) и микротерассы в зоне осушки

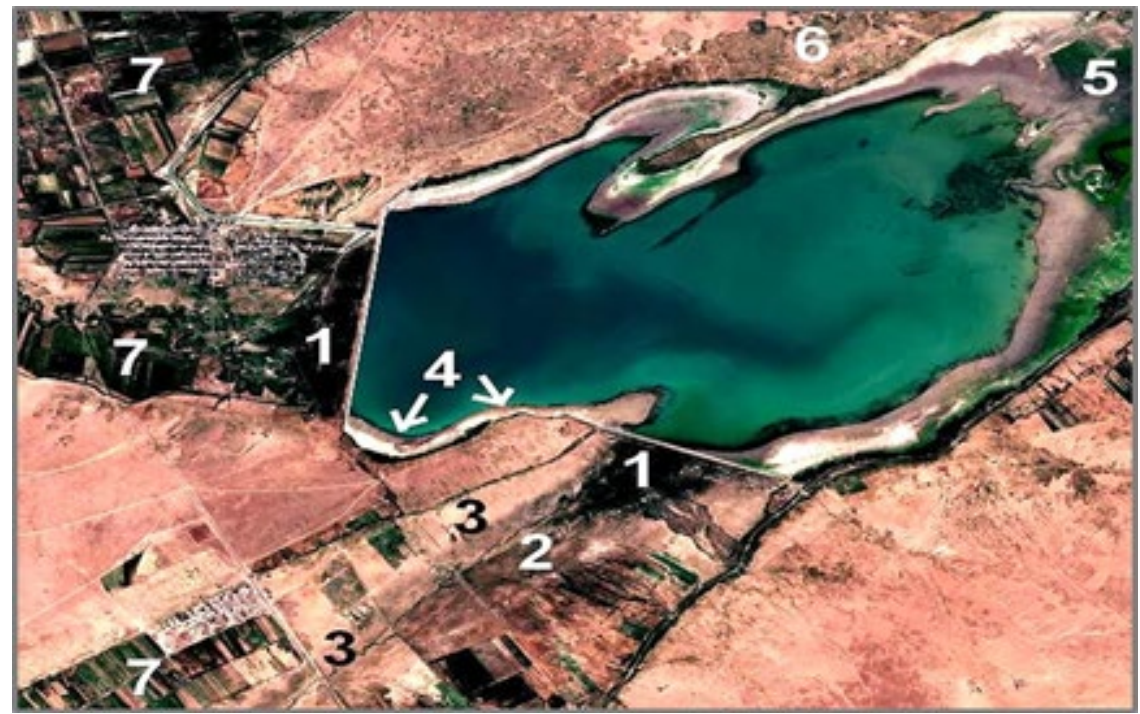

Рис.5. Влияние водохранилища на побережье: 1 - заболоченные засоленные почвы нижнего бьефа плотин; 2 -лугово-болотные и луговые засоленные почвы сая Каражантак; 3 - подтопленные лугово-сероземные солончаковые почвы; 4 - эрозионноопасные участки побережья; 5 - подтопленные незасоленные почвы верховья водохранилища; 6 - слабо подтопленные светлье сероземы с крупнотравной растительностью; 7 - орошаемье земли (снимок Сентинел-2 за 19.07.2019)

Эрозионные процессы на побережье водохранилища проявились уже в первые годы его наполнения (1963-1968 гг.). Наиболее сильно размывались лессовые берега левобережья под влиянием волновой деятельности во время сильных ветров. Берег отступал на десятки метров, создавая угрозы для 
безопасности Бугунской плотины (рис. 6). В последние годы скорость разрушения берегов уменьшилась. Если в среднем за период 1966-2019 гг. отступание берегов составило 7-11 м в год, то в 2000-е годы оно не превышало $1-2 \mathrm{M}$.
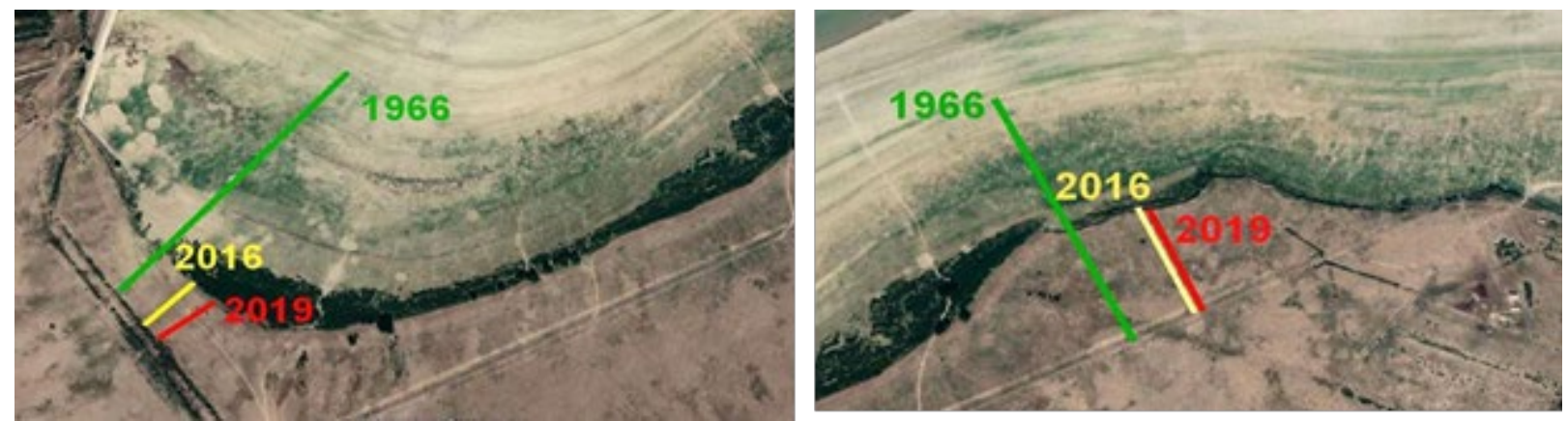

Рис.6. Динамика эрозии берегов Бугунского водохранилища

3. Арысский магистральный канал (АМК) длиной 51 км был сооружен для подачи воды в Бугунское водохранилище и далее в Туркестанский канал (ТМК). Он начинается от Караспанского барража на реке Арысь и огибает водораздельный увал между саем Каражантак и долиной Арыси (рис. 7). При этом планировалось орошать из канала АМК также часть земель западного склона этого увала и земли хозяйства Дармина (выращивание лекарственных трав для медицинских целей). Канал не имеет противофильтрационной облицовки, хотя он был прорыт в суглинистых отложениях с коэффициентом фильтрации 0,5-1,0 м/сутки и склонностью этих грунтов к просадкам. Кроме того, огибая названный увал по его подножию, канал неизбежно пересекал овраги и балки, что способствовало эрозии и неустойчивости его русла

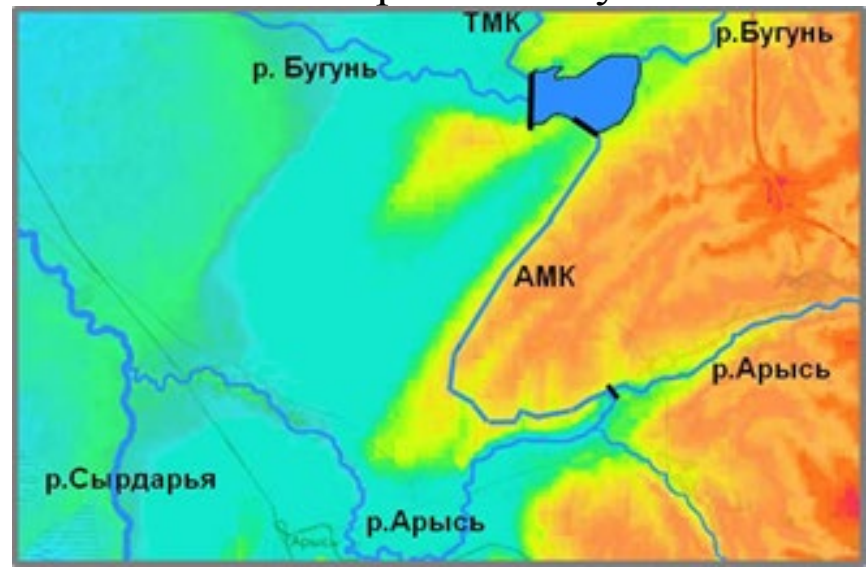

\section{Рис.7. Геоморфология района Арысского магистрального канала (АМК)}

Поскольку на оросительной системе (АТОС) предполагалось первоочередное освоение земель, подкомандных Туркестанскому магистральному каналу (ТМК), Арысский канал в первые годы выполнял задачу транспорта воды Арыси в Бугунское водохранилище и дальше в ТМК. Ирригационное освоение земель, непосредственно подкомандных АМК, осуществлялось постепенно по мере готовности инфраструктуры для использования водно-земельных ресурсов. Динамика развития орошения показана на снимках Ландсат и Сентинел (рис.8). 

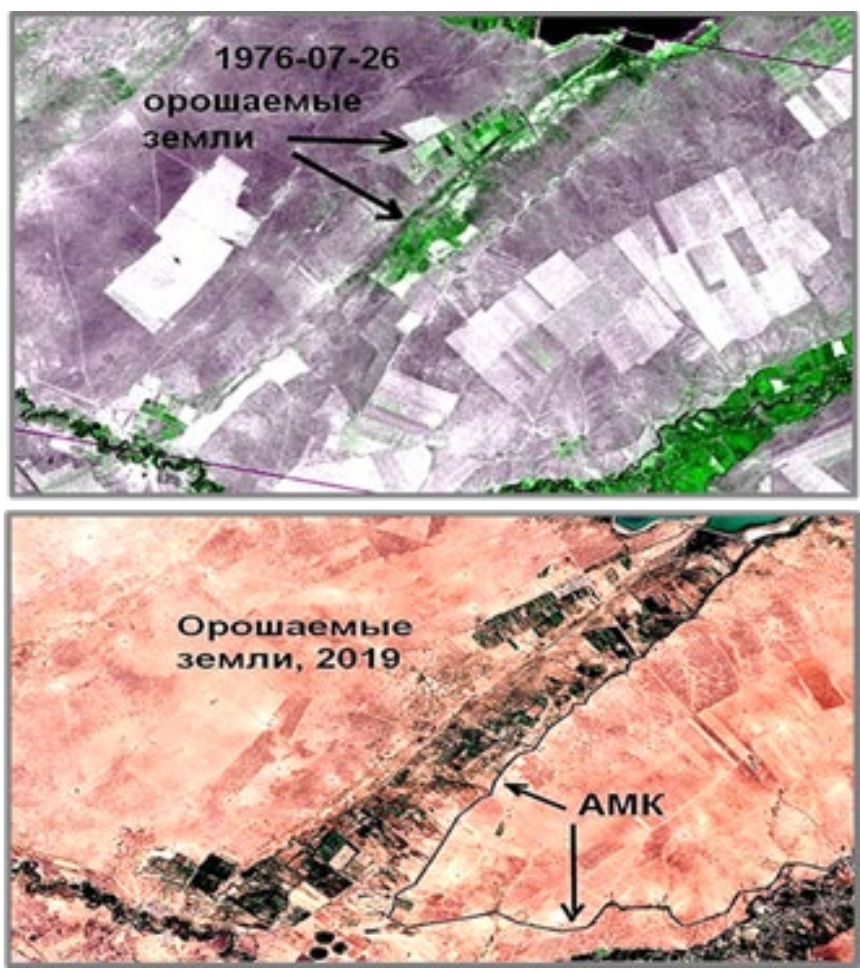

\section{Рис. 8. Развитие орошения на территории АМК}

Учитывая острую нехватку воды для орошения на всей системе, мы проанализировали возможные пункты непроизводительных потерь на самом АМК из-за неисправностей водораспределительных сооружений на нем, а также несанкционированного отбора воды из канала для местных потребителей несовершенными способами в последние годы (рис.9).

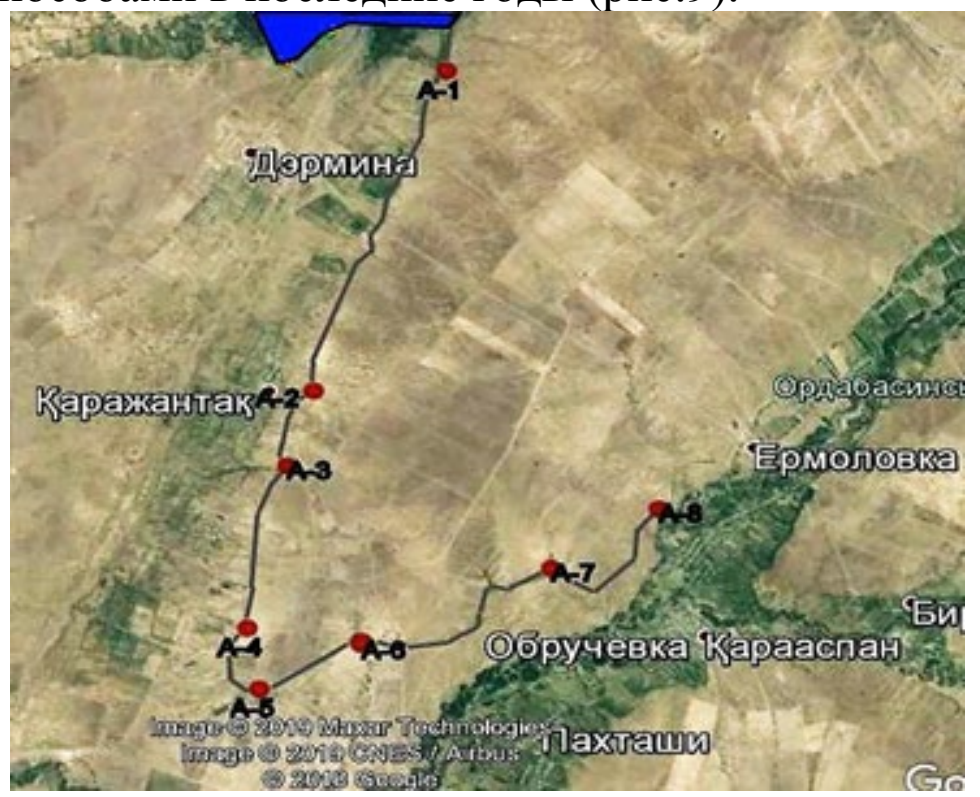

Рис. 9. Пункты потери воды из АМК

На всем АМК выявлено 8 пунктов потерь воды (рис. 9) с координатами:

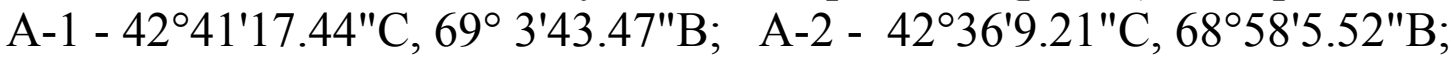

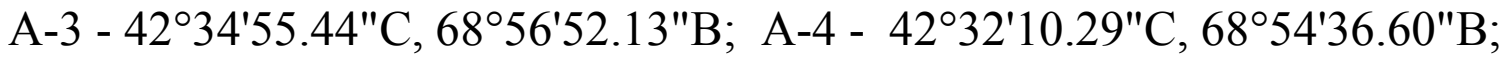

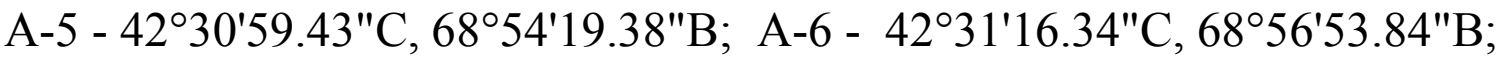

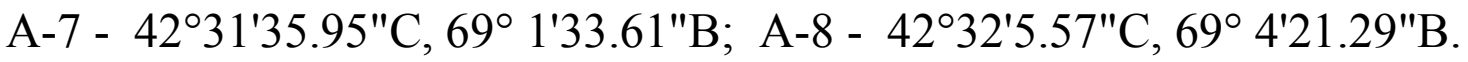


В этих пунктах выявлено: 1) сброс воды из АМК по поверхности склона (A-1); 2) частичное повреждение канала и подтопление земель при пересечении АМК крупных оврагов и балок (A-2, 3, 4, 7, 8); 3) подтопление земель при отведении воды из АМК упрощенным способом; 4) отведение воды непроектными распределительными каналами (А-6).

4. Туркестанский магистральный канал (ТМК) простирается от Бугунского водохранилища на востоке до пос. Сауран - на западе (рис. 10). Он обеспечивается водой из Бугунского водохранилища с расходами около 45 м3/с, а также в небольшой мере водой малых речек и временных водотоков, текущих со склонов хребта Каратау. Из ТМК по 48 распределительных каналов подают воду для орошения и водоснабжения в создаваемые в 60-е годы хлопководческие хозяйства (совхозы), в дальнейшем переименованные в соответствии с современными тенденциями, a земли которых трансформированы в фермерские хозяйства. В дальнейшем площади орошения из этих каналов и их конфигурация в определенной мере изменялись в соответствии с успешностью мелиорации и освоения земель, а также с интересами местного населения и развития новых социально-экономических отношений.

Ирригационное освоение земель, подкомандных ТМК, происходило со значительными сложностями (как уже отмечено во «Введении»), обусловленными особенностями литологического строения почво-грунтов, засолением почв, потерями воды на фильтрацию из каналов и орошаемых земель, специфическим формированием почвенно-мелиоративных условий (рис.11 и 12).

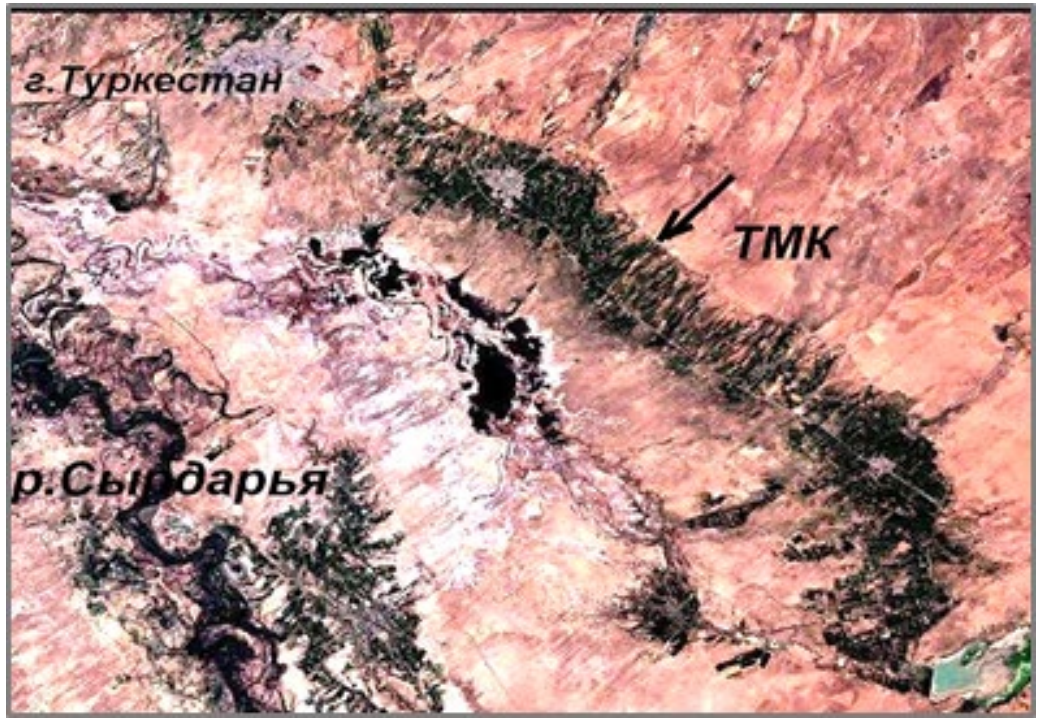

\section{Рис. 10. Туркестанский магистральный канал и массив орошения}

Дальнейшее развитие здесь орошения определяется недостатком воды, поэтому необходимо устранять непроизводительные потери из магистрального канала на фильтрацию в гравийно-галечниковые отложения, а также «утечку» воды из-за неудовлетворительного состояния некоторых сооружений на ТМК. 


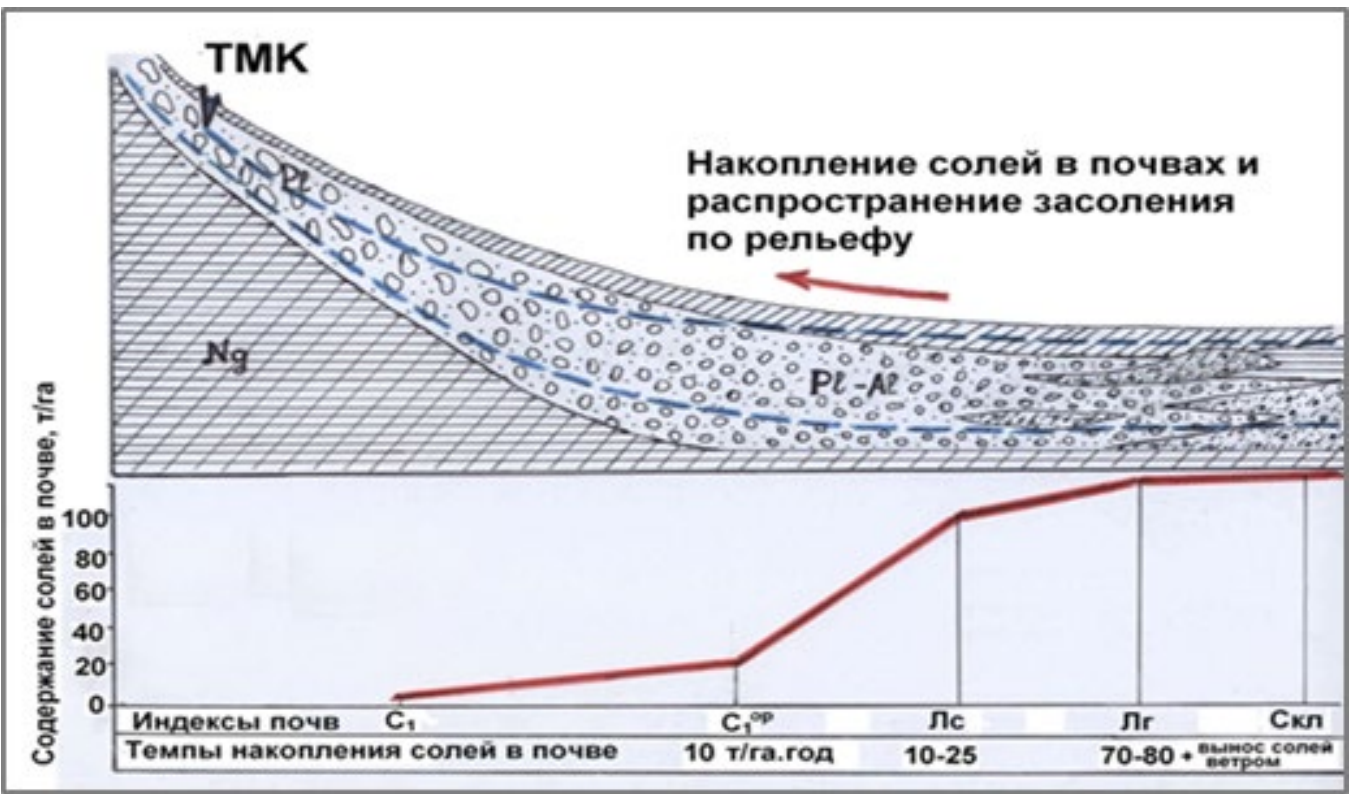

Рис. 11. Схематический литологический поперечный профиль территории, подкомандной ТМК, и накопление солей в почвах при

орошении (индексы почв: C1 - светлые сероземы, Clop-орочаемые светлые сероземы, Лс-лугово-сероземные почвы, Лг - луговые почвы, Скл-солончаки луговые).

Именно для этой задачи проведены наблюдения по всей трассе канала с помощью квадрокоптеров (дронов) и использованы материалы картографического сервиса "Google Earth" (рис.13).

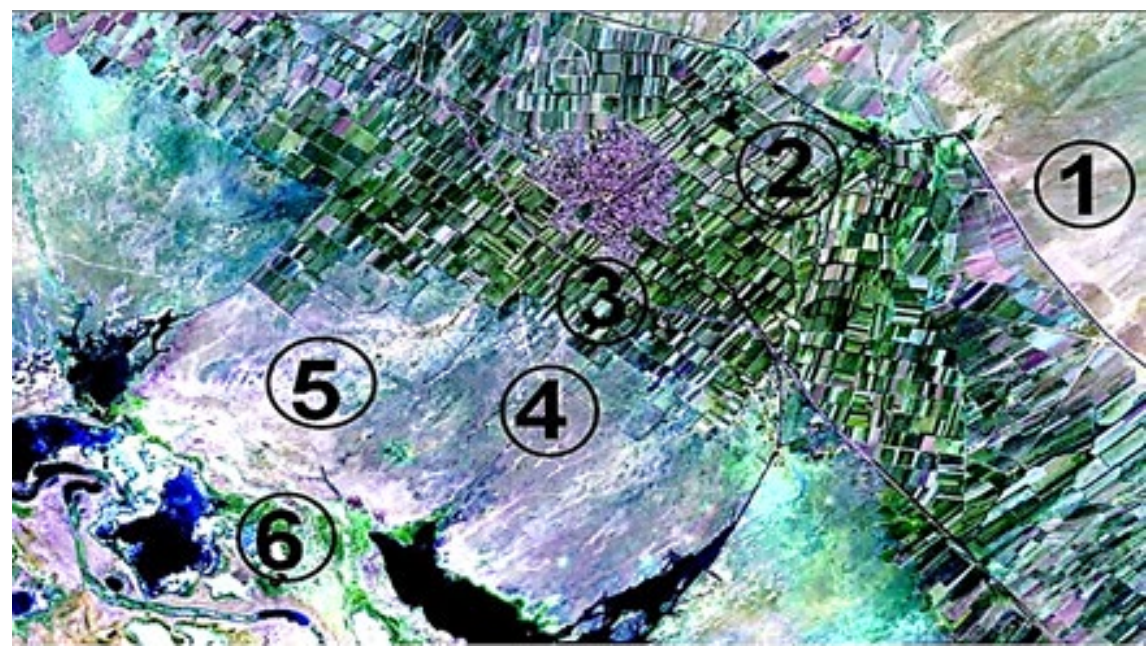

Рис.12. Почвенный покров подкомандной ТМК территории в 2019 г. в районе пос. Старый Икан: 1 -сероземы светлые северные (иелина), 2 - сероземы светлые северные (орошаемые), 3 - сероземы светлые глееватые, 4-лугово-сероземные почвы, 5 - сероземно-луговые засоленные почвы в комплексе с солончаками, 6 -луговые и лугово-болотные почвы. 


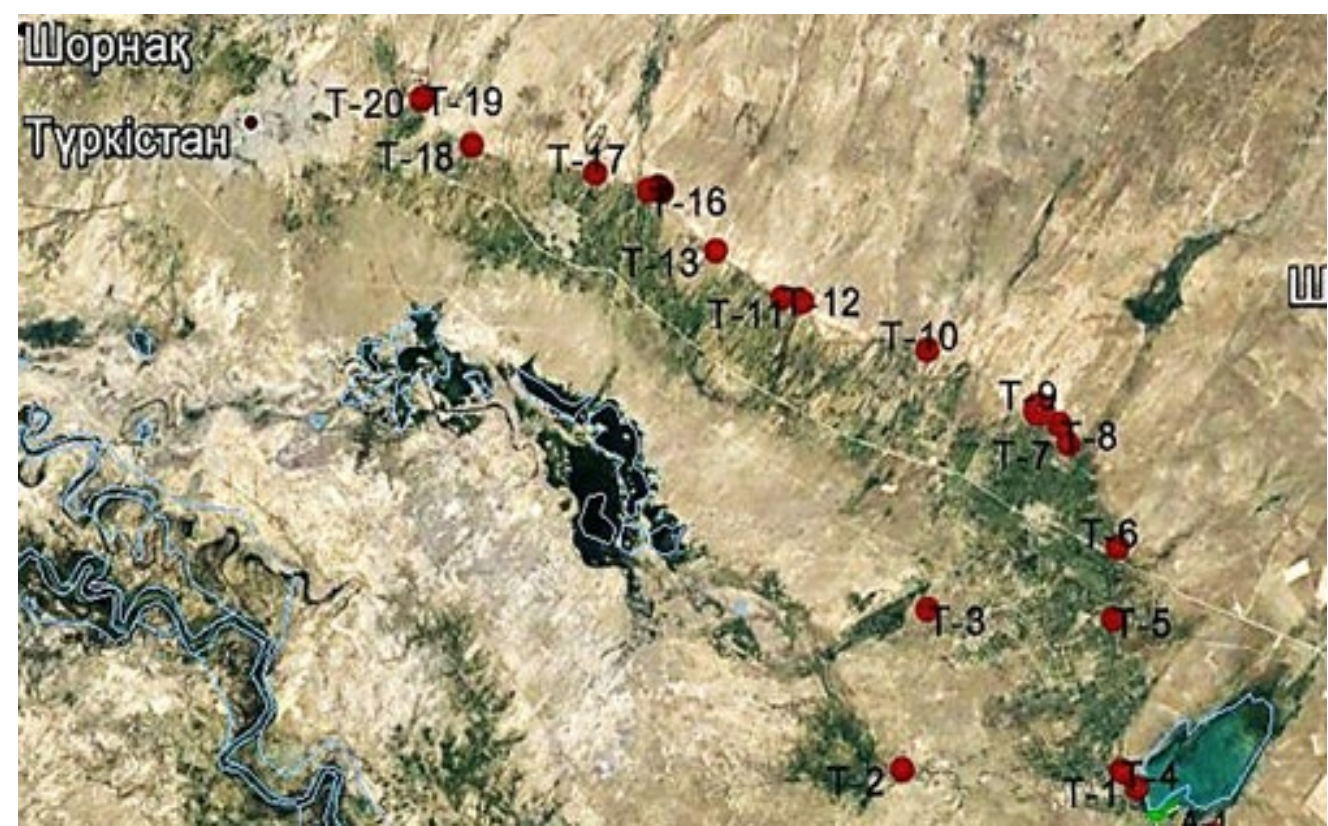

\section{Рис.13. Пункты потерь воды из ТМК}

На рис. 14 приведены типичные для ТМК потери воды из-за нерационального водопользования и технического состояния канала.

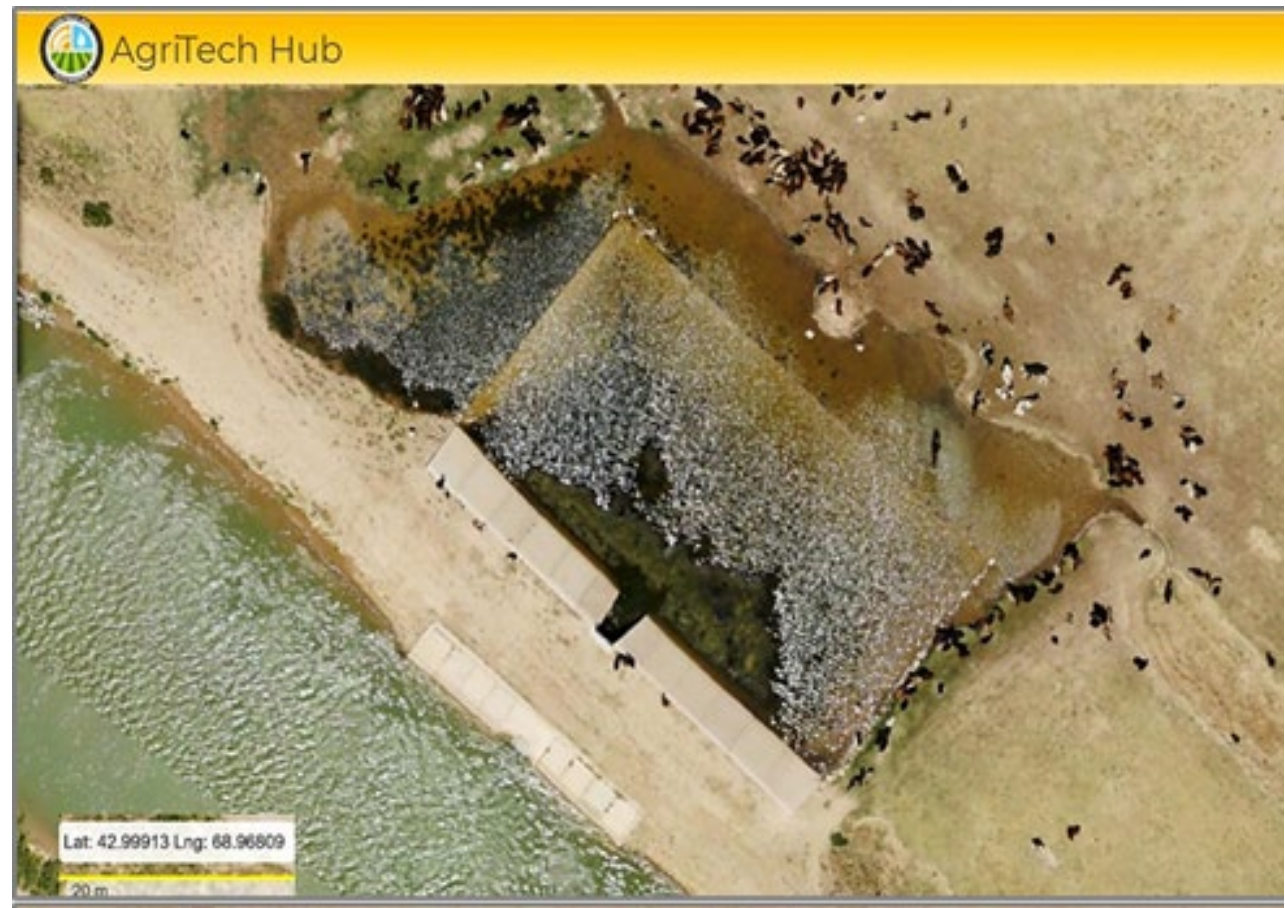

Рис. 14. Избыточное отведение воды из ТМК для водопоя скота, повреждающее откосы канала (Т-9, снимок квадрокоптером в 2019 г.) 

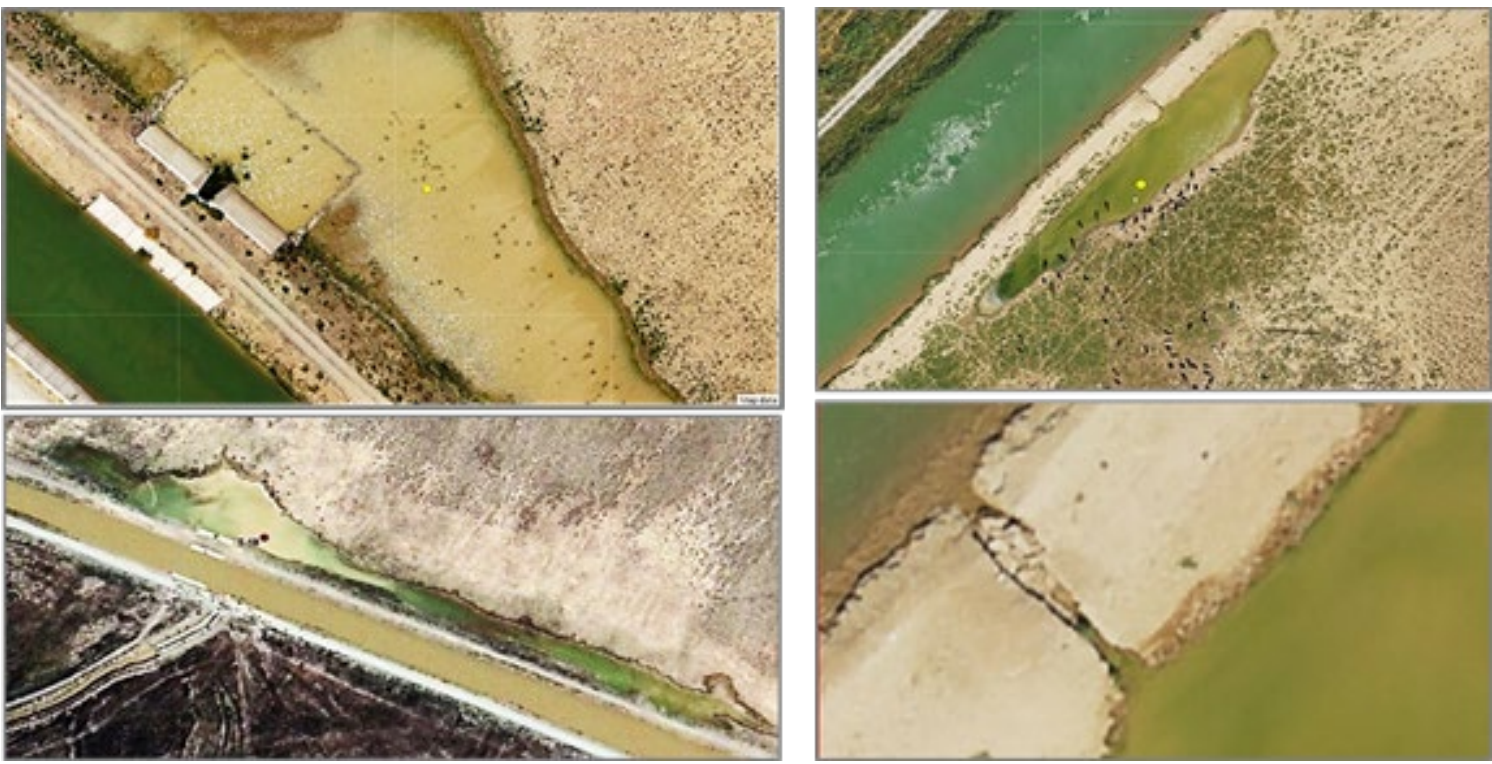

Рис.15. Разливы воды в пунктах водопоя скота при наличии оборудованного водовыпуска (слева, снимок дроном и его изображение на карте "Google Earth", T-13), а также при его отсутствии (справа).
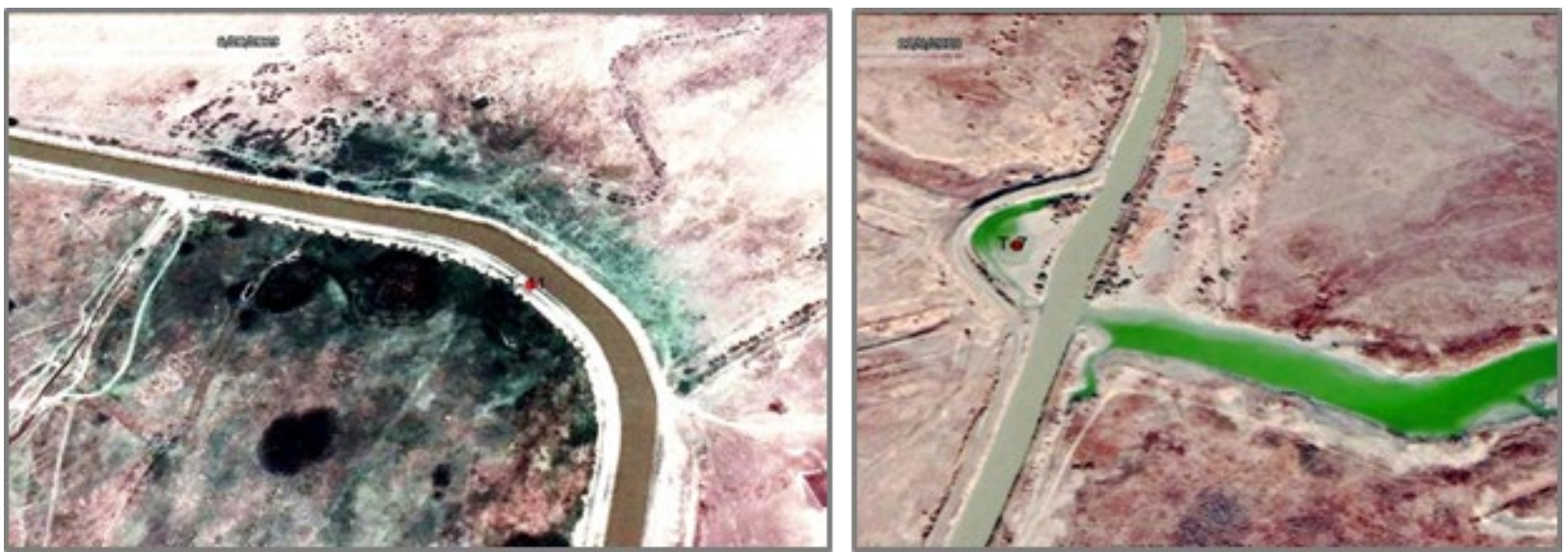

Рис.16. Затопление и подтопление смежных с ТМК земель, Т-11 (слева) и затопление земель при пересечении ТМК и р. Арыстанды, Т-7 (справа)

\section{Заключение.}

Оптимизация водопользования на Арысь-Туркестанской оросительной системе должна предусматривать комплекс мероприятий по уменьшению непроизводительных потерь во всем водохозяйственном комплексе. Первоочередным (по времени осуществления) должно быть устранение потерь воды из магистральных каналов АМК и ТМК, обусловленных техническим состоянием сооружений на них, а также несанкционированного водоотведения, особенно без должного инженерного обустройства таких пунктов. Наиболее важным, но требующим значительно большего времени и средств, является разработка и осуществление мероприятий по уменьшению фильтрационных потерь из магистральных каналов, особенно на участках с неглубоким залеганием галечников. Предстоит также длительная (многолетняя) работа по совершенствованию внутрихозяйственных оросительных и дренажных сетей, особенно в условиях разгосударствления земельных ресурсов, оптимизация 
технологий орошения и поливных и оросительных норм, подбор менее требовательных к воде сортов выращиваемых культур. Стратегически важной становится и проблема повышения водообеспеченности всей оросительной системы путем привлечения дополнительных водных ресурсов, прежде всего за счет перераспределения стока реки Арысь (создание Березовского водохранилища), а также за счет более полного использования подземных и коллекторно-сбросных вод.

\section{Литература.}

1. Аверьянов С.Ф. Заключение на уточненное проектное задание АрысьТуркестанского канала. - Фонды ин-та «Союзгипрорис». 1963.

2. Вышпольский Ф.Ф. Разработка и обоснование оптимальных норм для промывки засоленных почв на примере Арысь-Туркестанского массива. Автореф. Алма-Ата, 1971. - 22 с.

3. Егоричев Г.А., Стародубцев В.М. Почвенно-мелиоративные условия в зоне влияния Бугунского водохранилища // Проблемы мелиорации почв Средней Азии и Казахстана. - Изд. АН КазССР: Алма-Ата, 1970. - С. 280-285.

4. Жихарева Г.А., Курмангалиев А.Б., Соколов А.А. Почвы Каахской ССР. Вып.12. Почвы Чимкентской области. - Изд. АН КазССР: Алма-Ата, 1969. $412 \mathrm{c}$.

5. Ковда В.А., Егоров В.В. Оценка ландшафтов для ирригации и дренажа // Почвы аридной зоны как объект орошения. - Наука: Москва, 1968. - 116 с.

6. Соколов А.А. Природные зоны Казахстана // Агрохимическая характеристика почв СССР. Казахстан и Челябинская область. - Наука: Москва, 1968. - c. 9-24.

7. Стародубцев В.М. Водно-солевой режим и вопросы мелиоративного улучшения почв Арысь-Туркестанского массива. - Автореф. канд. дисс. АлмаАта, 1972. - 28 c.

8. Стародубцев В.М. Почвенно-мелиоративные процессы в зоне влияния водохранилищ // Проблемы освоения пустынь, - 1977. - №6. - С.18-26.

9. Стародубцев В.М. Влияние водохранилищ на почвы. Изд. Наука: АлмаАта, 1986. - 296 с.

10. Стародубцев В.М. Влияние Бугуньского водохранилища на побережье за 50 лет // Аридные экосистемы, 2012. - т.18. - № 2(51). - С. 91-97.

\section{References:}

1. Averyanov S.F. Conclusion on the updated design assignment of the Arys-Turkestan Canal. - Funds of the Institute "Soyuzgiproris". 1963.

2. Vyshpolsky F.F. Development and justification of optimal standards for washing saline soils using the Arys-Turkestan massif as an example. - Abstract. cand. diss. Alma-Ata, 1971.- 22 p.

3. Egorichev G.A., Starodubtsev V.M. Soil-reclamation conditions in the Bugun reservoir' zone of influence // Problems of soil reclamation in Central Asia and Kazakhstan. - Academy of Sciences of the Kazakh SSR: Alma-Ata, 1970 .- Pp. 280-285.

4. Zhikhareva G.A., Kurmangaliev A.B., Sokolov A.A. Soil of the Kazakh SSR. Issue 12. Soils of the Shymkent region. - Academy of Sciences of the Kazakh SSR: Alma-Ata, 1969 .- 412 p.

5. Kovda V.A., Egorov V.V. Assessment of landscapes for irrigation and drainage // Soils of the arid zone as an irrigation object. - Science: Moscow, 1968 .- 116 p. 
6. Sokolov A.A. Natural zones of Kazakhstan // Agrochemical characteristics of the soils of the USSR. Kazakhstan and Chelyabinsk region. - Science: Moscow, 1968. - p. 9-24.

7. Starodubtsev V.M. Water-salt regime and issues of soils reclamation improvement of the Arys-Turkestan massif. - Abstract. cand. diss. Alma-Ata, 1972.- 28 p.

8. Starodubtsev V.M. Soil-reclamation processes in the zone of reservoirs influence // Problems of desert development, - 1977. - No. 6. - p.18-26.

9. Starodubtsev V.M. The effect of reservoirs on soils. Science: Alma-Ata, 1986.- 296 p.

10. Starodubtsev V.M. The Influence of the Bugun Reservoir on the Coast for 50 Years // Arid Ecosystems, 2012.- vol. 18. - No. 2 (51). - p. 91-97.

Abstract: The history of the design and development of the Arys-Turkestan irrigation system created on the foothill plain in Southern Kazakhstan is considered. Specific reclamation features of this territory, which represents the peripheral part of the merged cones (fens) of the the Karatau ridge southwestern slopes, are noted. Particular attention is paid to the influence of the irrigation Bugun reservoir on adjacent territories, in particular the processes of soil salinization, submergence and erosion. On the Arys (AMC) and Turkestan (TMC) canals, areas of unproductive water losses due to the state of hydraulic structures were identified using drones and the Google Earth mapping service. The dynamics of the irrigation development is analyzed, taking into account soil salinization, waterlogging and drainage use. Measures are proposed to improve the water supply for the irrigation system.

Key words: debris cones, irrigation, soil salinization, waterlogging, dranage. 